This item was submitted to Loughborough's Research Repository by the author.

Items in Figshare are protected by copyright, with all rights reserved, unless otherwise indicated.

\title{
An experimental study into the effect of the pilot injection timing on the performance and emissions of a high-speed common-rail dual-fuel engine
}

\section{PLEASE CITE THE PUBLISHED VERSION}

https://doi.org/10.1177/0954407013506180

\section{PUBLISHER}

(C) The authors. Published by SAGE Journals

\section{VERSION}

AM (Accepted Manuscript)

\section{PUBLISHER STATEMENT}

This work is made available according to the conditions of the Creative Commons Attribution-NonCommercialNoDerivatives 4.0 International (CC BY-NC-ND 4.0) licence. Full details of this licence are available at: https://creativecommons.org/licenses/by-nc-nd/4.0/

\section{LICENCE}

CC BY-NC-ND 4.0

\section{REPOSITORY RECORD}

Rimmer, John E.T., Stephen Johnson, and Andrew Clarke. 2014. "An Experimental Study into the Effect of the Pilot Injection Timing on the Performance and Emissions of a High-speed Common-rail Dual-fuel Engine”. Loughborough University. https://hdl.handle.net/2134/27192. 


\title{
An experimental study into the effect of pilot injection timing on the performance and emissions of a high speed common rail dual fuel engine
}

\author{
John ET Rimmer, Stephen L Johnson, Andrew Clarke
}

Wolfson School of Mechanical and Manufacturing Engineering, Loughborough University, UK

\section{Corresponding author:}

Andrew Clarke, Wolfson School of Mechanical and Manufacturing Engineering, Loughborough University, Loughborough, Leicestershire, LE11 3TU, UK

Email: a.clarke@lboro.ac.uk

\begin{abstract}
Dual fuel technology has the potential to offer significant improvements in emissions of carbon dioxide from light-duty compression ignition engines. In these smaller capacity high speed engines, where the combustion event can be temporally shorter, the injection timing can have an important effect on the performance and emissions characteristics of the engine. This paper discusses the use of a 0.51-litre single-cylinder high speed direct injection diesel engine modified to achieve port directed gas injection. The effect of pilot diesel injection timing on dual fuel engine performance and emissions was investigated at engine speeds of 1500 and $2500 \mathrm{rpm}$ and loads equivalent to $0.15,0.3,0.45$ and $0.6 \mathrm{MPa}$ gross indicated mean effective pressure, for a fixed gas substitution ratio (on an energy basis) of $50 \%$. Furthermore, the effect of pilot injection quantity was investigated at a constant engine speed of $1500 \mathrm{rpm}$ by completing a gaseous substitution sweep at the optimised injection timing for each load condition. The results identify the limits of single injection timing during dual fuel combustion and the gains in engine performance and stability that can be achieved through optimisation of the pilot injection timing.
\end{abstract}


Furthermore, pilot injection timing and quantity were shown to have fundamental effects on the formation and emission of carbon monoxide, nitrogen oxide and total hydrocarbons. The potential for dual fuel combustion to achieve significant reductions in specific $\mathrm{CO}_{2}$ was also highlighted, with reductions of up to $30 \%$ being achieved at full load compared to the baseline diesel case.

\section{Keywords:}

Dual fuel, high speed, injection timing, substitution ratio, methane injection, combustion

\section{Introduction}

There is currently considerable interest in new engine technologies to assist in the reduction of carbon dioxide $\left(\mathrm{CO}_{2}\right)$ emissions from light-duty vehicles. In Europe, this is driven by legislation established under a commitment by the European Automobile Manufacturers Association to the European Union to reduce automotive $\mathrm{CO}_{2}$ emissions. ${ }^{1}$ The application of dual fuel technology to light-duty compression ignition engines has the potential for significant reductions in $\mathrm{CO}_{2}$ emissions. ${ }^{2}$ This is due to the replacement of the diesel fuel with a gaseous fuel that has a lower carbon-to-hydrogen ratio. Typically, methane, the main constituent of natural gas ( 94\% by vol. in the UK), is the preferred fuel for the use in dual fuel engines as it is highly knock resistant ${ }^{3}$ and contains more energy per unit mass than other conventional fuels ${ }^{4}$. The term 'dual fuel' refers to a compression ignition engine in which a charge of air and quantity of gaseous fuel are simultaneously ingested to form a lean premixed charge. ${ }^{5}$ The lean mixture is subsequently compressed and near the end of the compression stroke a small quantity of diesel fuel (the pilot fuel) is injected into the cylinder. After a delay period, this pilot fuel ignites and both the pilot diesel fuel and the lean mixture of gaseous fuel and air combust. 
The barrier to the use of dual fuel technologies in light-duty diesel engines is a result of the high engine speeds required for these smaller capacity engines, resulting in temporally shorter combustion events. This is a concern for dual fuel combustion, which has longer ignition delay times and slower rates of combustion compared to conventional diesel. Furthermore, at light load, the lean air-fuel mixture inducted into the engine is difficult to ignite and slow to burn. Consequently, oxidation reactions are slow and incomplete, resulting in increased levels of unburned hydrocarbon (uHC) and carbon monoxide (CO) emissions. ${ }^{6}$ At high loads, the gaseous mixture is rich enough to achieve stable flame propagation throughout the cylinder charge. This allows for improved thermal efficiency, although the higher cylinder temperatures lead to increased $\mathrm{NO}_{\mathrm{x}}$ emissions compared to conventional diesel combustion. ${ }^{7}$

The aim of the research discussed within this paper was to investigate the effect of single pilot injection timing and quantity on dual fuel engine performance and emissions in a high speed engine. Although there are number of journal papers reporting pilot injection studies on dual fuel engines, ref 8 for example, they predominately use out dated fuel injection technologies and hence there is a dearth of information regarding dual fuel engines using high pressure common rail injection technologies. For this research, dual fuel operation was achieved through a port injection gas system. In-cylinder pressures and heat release rates are compared at engine speeds of 1500 and $2500 \mathrm{rpm}$ and loads of 0.15, 0.3, 0.45 and 0.6 MPa gross indicated mean effective pressure (IMEP $)$, for a range of injection timings at a fixed gas substitution ratio (on an energy basis) of 50\%. Furthermore, in-cylinder pressures and heat release rates are compared at $1500 \mathrm{rpm}$ for a range of pilot quantities, by completing a gaseous substitution sweep at the optimised injection timing for each load condition. 


\section{Experimental configuration}

\section{Test facility}

The engine test facility used to complete this research was based on an AVL 5402 single-cylinder high speed direct injection diesel engine, details of which are included in Table $1 .^{9}$ The four valve cylinder head consisted of two inlet and two exhaust valves per cylinder with double overhead camshaft valvetrain. This engine facility being representative of a single-cylinder version of a typical 2-litre, four cylinder automotive high speed direct injection diesel engine.

Table 1. AVL 5402 engine specifications

\begin{tabular}{ll}
\hline Rated speed & $4200 \mathrm{rpm}$ \\
Bore & $85 \mathrm{~mm}$ \\
Stroke & $90 \mathrm{~mm}$ \\
Compression ratio & 17.1 \\
Swept volume & $510.7 \mathrm{~cm}^{3}$ \\
Chamber geometry & Re-entrant bowl in piston \\
Intake ports & Tangential and swirl \\
Swirl ratio & 1.78 \\
Intake valve opening & $346{ }^{\circ} \mathrm{CA}$ ATDC \\
Intake valve closing & $586.5^{\circ} \mathrm{CA}$ ATDC \\
Exhaust valve opening & $128.5^{\circ} \mathrm{CA}$ ATDC \\
Exhaust valve closing & $376.5^{\circ} \mathrm{CA}$ ATDC \\
\hline
\end{tabular}

${ }^{\circ} \mathrm{CA}$ ATDC - Degrees crank angle after top dead centre

Diesel fuel was injected directly into the cylinder using a Bosch common rail CP3 injection system, consisting of a production type high-pressure common rail fuel pump supplying fuel to the injector at 
pressures of up to $135.0 \mathrm{MPa}$, independent of engine speed. Further details of the fuelling system are included in Table 2. The fuel injection control system consisted of a prototype ETAS engine control unit, which was controlled and monitored through INCA $^{\mathrm{TM}}$ software using an open loop fuel injection control strategy designed by AVL. This system permitted independent control of the timing and duration of up to four injection events per engine cycle.

Table 2. Fuelling system specification

\begin{tabular}{ll}
\hline Fuel injection system & Bosch CP3 common rail \\
Maximum rail pressure & $135.0 \mathrm{MPa}$ \\
Nozzle type & Valve covered orifice (VCO) \\
Number of holes & 5 \\
Hole diameter & $0.18 \mathrm{~mm}$ \\
Spray included angle & $142^{\circ}$ \\
\hline
\end{tabular}

The diesel fuel used to complete this research was an automotive grade sulphur-free diesel (sulphur content $<10$ mg. $\mathrm{kg}^{-1}$ ) that meets the current British Standard BS EN 590 and complies with the current requirements of the UK "Motor Fuel (Composition and Content) Regulations”. Table 3 provides further details of the diesel fuel composition.

Table 3. Diesel fuel details

\begin{tabular}{ll}
\hline Density at $15^{\circ} \mathrm{C}$ & $840 \mathrm{~kg} \cdot \mathrm{m}^{-3}$ \\
Polycyclic aromatic hydrocarbons (PAH) & $9 \%$ \\
Sulphur contents & $8 \mathrm{mg} \cdot \mathrm{kg}^{-1}$ \\
Cetane number & 52 \\
\hline
\end{tabular}


To operate the engine in dual fuel mode, a gaseous port injection system was designed, allowing for precise metering and control of the gaseous fuel. ${ }^{2}$ Dual fuel combustion was achieved through the use of a twin port injection system, providing equal fuel delivery into the swirl and tangential ports. The methane gas, properties of which are provided in Table 4, was supplied via a gas cylinder located outside of the engine test facility. The outlet from the gas cylinder was passed through a two-stage pressure regulator, isolation valve and a solenoid actuated shut-off valve before being supplied to the common rail for the two gas injectors. The gas injectors were independently controlled through an in-house designed driver unit, allowing each injector to be activated/deactivated, injection timing to be specified and injection duration controlled. For all tested engine speeds and loads the start of methane injection was timed to occur immediately following exhaust valve closure $\left(376.5^{\circ} \mathrm{CA}\right)$, maximising the time available for mixing within the cylinder. The injector driver was independently powered from a $14 \mathrm{~V}$, $8 \mathrm{~A}$ maximum power supply ensuring a consistent power source for the injectors.

Table 4. Methane specification (CP (N2.5) grade, supplied by BOC gases)

\begin{tabular}{ll}
\hline Molecular weight & 16 \\
Density at STP & $0.647 \mathrm{~kg} \cdot \mathrm{m}^{3}$ \\
Lower heating value & $50.05{\mathrm{MJ} . \mathrm{kg}^{-1}}^{-16}$ \\
Stoichiometric air fuel ratio & 17.2 \\
Cetane number & $\sim 0$ \\
Flammability limits, upper/lower & $15 / 5$ (\% by volume) \\
Autoignition temperature & $580^{\circ} \mathrm{C}$ \\
\hline
\end{tabular}

STP - Standard temperature and pressure

The research engine was coupled to an AMK DW engine dynamometer rated at $38 \mathrm{~kW}$. Surge tanks on the intake and exhaust streams were used to damp out the pressure oscillations inherent in single-cylinder 
engine operation. The intake air temperature was also controlled using an intake heater, capable of achieving air temperatures between $40^{\circ} \mathrm{C}$ and $140^{\circ} \mathrm{C}$. A schematic diagram of the research facility is illustrated in Figure 1.

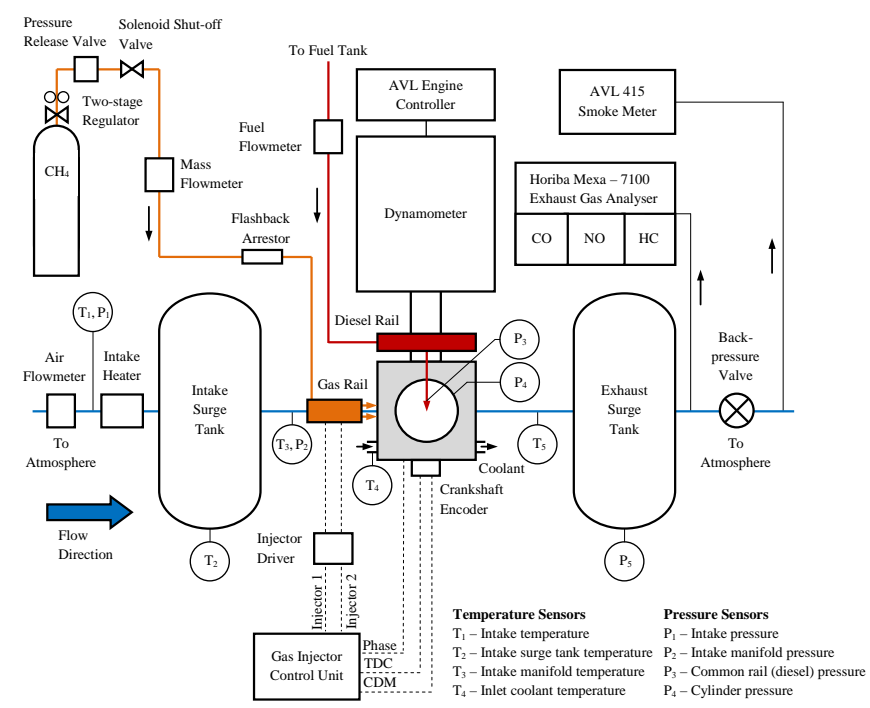

Figure 1. Schematic diagram of the AVL engine test facility including dual fuel installation

In-cylinder pressure measurements were obtained using a flush-mounted, water-cooled piezoelectric pressure transducer and the intake air manifold pressure using a piezoresistive transducer. These measurements were both captured at $0.5{ }^{\circ} \mathrm{CA}$ increments, defined through the use of an optical crankshaft encoder. At each tested engine operating condition the raw in-cylinder pressure data was captured over 200 consecutive engine cycles.

Emissions of $\mathrm{CO}, \mathrm{CO}_{2}$, total hydrocarbons $(\mathrm{tHC})$, nitrogen oxide $\left(\mathrm{NO}_{\mathrm{x}}\right)$ and oxygen $\left(\mathrm{O}_{2}\right)$ were measured using a Horiba Mexa 7100HEGR exhaust gas analyser and smoke emissions were measured using an AVL 415 smoke meter. Emissions of both $\mathrm{CO}$ and $\mathrm{CO}_{2}$ were measured using a non-dispersive infra-red 
analyser, $\mathrm{NO}_{\mathrm{x}}$ using a chemiluminescence analyser, tHC using a flame ionisation detector and $\mathrm{O}_{2}$ using a magnetopneumatic condenser microphone. At each engine operating condition, raw emissions data were recorded at a frequency of $1 \mathrm{~Hz}$ over a period of 4 minutes.

\section{Analysis procedure}

\section{In-cylinder pressure data}

A processing routine was developed within MATLAB ${ }^{\mathrm{TM}}$ to analyse the pressure data captured over multiple engine tests. The analysis program was designed to load multiple sets of data and filter the raw pressure data to remove spurious frequency components associated with electronic noise within the signal. The filtered pressure data was then used to calculate a range of pressure derivatives, including rate of heat release (RoHR) and IMEPg.

\section{Rate of heat release (RoHR)}

The instantaneous apparent net rate of heat release is defined as the difference between the energy released due to combustion of the fuel and the energy loss due to heat transfer and crevice flows. The RoHR $(d Q / d \theta)$ is calculated from the in-cylinder pressure data for each individual engine cycle as follows $^{10}$

$\frac{d Q}{d \theta}=\frac{\gamma}{\gamma-1} P \frac{d V}{d \theta}+\frac{1}{\gamma-1} V \frac{d P}{d \theta}$

where $\theta$ is the crank angle, $\gamma$ is the specific heat ratio $(\gamma=1.33$, assumed constant), $P$ is the cylinder pressure, $V$ is the cylinder volume, $d V$ is the change in cylinder volume and $d P$ is the change in cylinder pressure. Integrating the heat release rate up to a specific crank angle and normalising it by the 
cumulative heat release provides the fraction of heat released up to that point. Typical points of interest included in this research are combustion phasings of $10 \%$ and $95 \%$ of the cumulative heat release, designated as CA10 and CA95 respectively.

\section{Indicated mean effective pressure}

Integrating the in-cylinder work over the compression and expansion strokes and normalising with the engine swept volume $\left(V_{d}\right)$ gives the gross indicated mean effective pressure (IMEPg), as defined in Heywood $^{9}$ as

$\operatorname{IMEP}_{\mathrm{g}}=\frac{1}{V_{d}} \int_{\theta=180^{\circ} \mathrm{CA}}^{\theta=540^{\circ} \mathrm{CA}} \mathrm{PdV}$

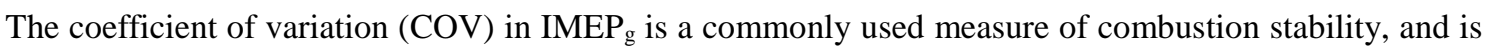
defined as the ratio of standard deviation $(\sigma)$ to the mean $(\mu)$ of the IMEPg.

\section{Gross indicated thermal efficiency}

The gross indicated thermal efficiency ( $\left.\eta_{\text {th,gross }}\right)$ was used as an indicator of the engine efficiency throughout this research, calculated as follows

$\eta_{\text {th,gross }}=\left(\frac{\mathrm{IMEP} \cdot V_{d}}{m_{\mathrm{CH}_{4}} L H V_{\mathrm{CH}_{4}}+m_{\text {diesel }} L H V_{\text {diesel }}}\right) 100 \%$

where $m$ is the mass of fuel, $L H V$ is the lower heating value and the subscripts $\mathrm{CH}_{4}$ and diesel denote methane and diesel respectively. 


\section{Operating conditions}

The aim of the research discussed within this paper was to further understand the effect of pilot injection timing and quantity on dual fuel combustion and emissions over a range of engine speeds and loads. To achieve this, engine testing was completed at two engine speeds of 1500 and 2500 rpm and loads of 0.15 , 0.3, 0.45 and 0.6 MPa IMEP $\mathrm{g}_{\mathrm{g}}$ equivalent to quarter, half, three-quarter and full load operating conditions (naturally aspirated). Throughout testing the coolant temperature and oil temperature were maintained at $80^{\circ} \mathrm{C}$ and $90^{\circ} \mathrm{C}$ respectively, while the intake air temperature was also maintained at $27^{\circ} \mathrm{C}$.

Baseline diesel testing was first completed at each engine speed and load operating condition to establish the optimum diesel fuel injection timing and quantity, such that the mechanical limitations of the engine were not exceeded. Notably, a maximum cylinder pressure of $17.0 \mathrm{MPa}$ and maximum rate of pressure rise of 1.0 MPa.deg-1 . To satisfy these limits under diesel combustion, it was necessary to introduce a pilot injection to limit the maximum rate of pressure rise. This pilot injection was required for all engine loads with the exception of the $0.15 \mathrm{MPa} \mathrm{IMEP}_{\mathrm{g}}$ case. Further details of the injection timings and fuelling rates for conventional diesel combustion are included in Table 5. 
Table 5. Baseline diesel injection timings and fuel flow rates

\begin{tabular}{|c|c|c|c|c|}
\hline \multirow{2}{*}{$\begin{array}{l}\text { Speed } \\
{[\mathrm{rpm}]}\end{array}$} & \multirow{2}{*}{$\begin{array}{c}\text { Load } \\
\left(\mathrm{IMEP}_{\mathrm{g}}\right) \\
{[\mathrm{MPa}]}\end{array}$} & \multicolumn{2}{|c|}{$\begin{array}{c}\text { Injection Timing } \\
\text { ( }{ }^{\circ} \mathrm{CA} \text { BTDC) }\end{array}$} & \multirow{2}{*}{$\begin{array}{l}\text { Diesel flow rate } \\
\qquad\left[\mathrm{kg} \cdot \mathrm{hr}^{-1}\right]\end{array}$} \\
\hline & & Pilot & Main & \\
\hline \multirow{4}{*}{1500} & 0.15 & 4.5 & - & 0.178 \\
\hline & 0.3 & 25.1 & 1.9 & 0.347 \\
\hline & 0.45 & 25.1 & 4.1 & 0.520 \\
\hline & 0.6 & 25.1 & 4.1 & 0.713 \\
\hline \multirow{4}{*}{2500} & 0.15 & 9.38 & - & 0.304 \\
\hline & 0.3 & 25.1 & 7.5 & 0.539 \\
\hline & 0.45 & 25.1 & 9.75 & 0.825 \\
\hline & 0.6 & 25.1 & 12.38 & 1.178 \\
\hline
\end{tabular}

$\mathrm{IMEP}_{\mathrm{g}}$ - Gross indicated mean effective pressure

${ }^{\circ} \mathrm{CA}$ BTDC - Degrees crank angle before top dead centre

The purpose of the baseline diesel testing was to establish the required fuelling rates, and therefore the fuel energy input to achieve a specific engine load at a given speed. During dual fuel combustion a proportion of this total diesel fuel energy was replaced by that contained within the gaseous methane. Consequently, the total combined fuel energy entering the cylinder remained constant between the dual fuel and baseline diesel cases at the specific engine speed and load operating conditions. Consequently, this has an effect on the performance and emissions during dual fuel combustion. Therefore, to differentiate between the load achieved during dual fuel combustion and the equivalent load under conventional diesel combustion, the latter is denoted $\mathrm{IMEP}_{\mathrm{g}}{ }^{*}$ throughout the remaining sections of this paper. The ratio of energy content between the gaseous fuel (methane) and the diesel fuel is defined by the substitution ratio $(x)$, and is calculated as follows 
$x=\left(\frac{m_{C_{4}} L H V_{C_{4}}}{m_{C_{4}} L H V_{C_{4}}+m_{\text {diesel }} L H V_{\text {diesel }}}\right) 100 \%$

Conventional diesel combustion is therefore defined by a substitution ratio of $x=0 \%$ and dual fuel combustion by a substitution ratio of $x>0 \%$.

Dual fuel testing was divided into two main sections. Firstly, a single pilot injection timing sweep was completed. Secondly, to investigate the effect of pilot injection quantity on dual fuel combustion a substitution ratio sweep at the optimum single pilot injection timing was completed. The effect of a single pilot injection on dual fuel combustion was investigated at 1500 and $2500 \mathrm{rpm}$ for engine loads of 0.15, 0.3, 0.45 and 0.6 MPa IMEP , for a fixed substitution ratio of $x=50 \%$. At each dual fuel operating condition the maximum pilot injection timing advance was first established, defined by a $\mathrm{COV}_{\mathrm{IMEPg}}>5 \%$. The pilot injection timing was then incrementally retarded towards top dead centre (TDC) until the

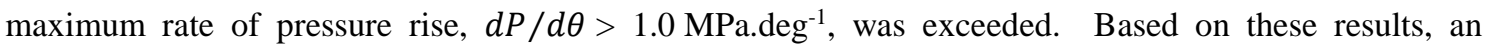
optimum single pilot injection timing was established and a substitution ratio sweep completed. Details of the single injection timings achieved at each engine speed and load operating condition are included in Table 6. Results highlighted that at all engine speed/load operating conditions, with the exception of $2500 \mathrm{rpm}, 0.6 \mathrm{MPa} \mathrm{IMEP}_{\mathrm{g}}{ }^{*}$, a $12{ }^{\circ} \mathrm{CA}$ range in pilot injection timing was achievable. At the highest speed and load condition, there was only a $3{ }^{\circ} \mathrm{CA}$ achievable injection timing range between the advance/retard limits. Consequently, at this high speed and high load operating condition a smaller incremental change in injection timing of $0.75{ }^{\circ} \mathrm{CA}$ was selected, compared to $3{ }^{\circ} \mathrm{CA}$ increments for all other cases. 
Table 6. Single pilot injection timing limits

\begin{tabular}{|c|c|c|c|c|}
\hline \multirow{2}{*}{$\begin{array}{l}\text { Speed } \\
\text { [rpm] }\end{array}$} & \multirow{2}{*}{$\begin{array}{c}\text { Load } \\
\left(\mathrm{IMEP}_{\mathrm{g}} *\right) \\
{[\mathrm{MPa}]}\end{array}$} & \multicolumn{3}{|c|}{$\begin{array}{l}\text { Pilot Injection Timing Limits } \\
\qquad\left({ }^{\circ} \mathrm{CA} \text { BTDC) }\right.\end{array}$} \\
\hline & & Advanced $^{1}$ & Retarded $^{2}$ & Increment \\
\hline \multirow{4}{*}{1500} & 0.15 & - & - & - \\
\hline & 0.3 & 24 & 12 & 3 \\
\hline & 0.45 & 36 & 21 & 3 \\
\hline & 0.6 & 48 & 36 & 3 \\
\hline \multirow{4}{*}{2500} & 0.15 & - & - & - \\
\hline & 0.3 & 27 & 15 & 3 \\
\hline & 0.45 & 39 & 27 & 3 \\
\hline & 0.66 & 57 & 54 & 0.75 \\
\hline
\end{tabular}

IMEP $_{\mathrm{g}}^{*}$ - Gross indicated mean effective pressure achieved under diesel combustion

${ }^{\circ} \mathrm{CA}$ BTDC - Degrees crank angle before top dead centre

1 - Limited by COVIMEPg $>5 \%$

2 - Limited by rate of pressure rise, $d P / d \theta>1.0{\mathrm{MPa} . \mathrm{deg}^{-1}}^{-1}$

\section{Results and discussion}

This section discusses the experimental results concerning the effect of pilot injection timing and quantity on dual fuel engine performance and emissions. With regards to engine performance, comparison of peak cylinder pressure, heat release rates, $\mathrm{IMEP}_{\mathrm{g}}$ and gross indicated thermal efficiency are made between dual fuel and conventional diesel combustion. Results are presented for engine speeds of 1500 and $2500 \mathrm{rpm}$ and loads of $0.3,0.45$ and $0.6 \mathrm{MPa} \mathrm{IMEP}_{\mathrm{g}}{ }^{*}$, equivalent to half, three-quarter and full load. The quarter load operating condition has been omitted since the calculated IMEP $\mathrm{g}_{\mathrm{g}}$ from dual fuel combustion was significantly less than the baseline diesel load of $0.15 \mathrm{MPa} \mathrm{IMEP}_{\mathrm{g}}{ }^{*}$. With regards to dual fuel engine 
emissions, the specific emission of nitrogen oxide, carbon monoxide, total unburned hydrocarbons and carbon dioxide are reported in terms of g.kWh${ }^{-1}$.

\section{Pilot injection timing}

Dual fuel engine performance. Figure 3 presents the mean cylinder pressure trace and cumulative heat release profiles at half and full load (0.3 and 0.6 $\mathrm{MPa}_{\mathrm{IMEP}}{ }^{*}$ respectively), at engine speeds of 1500 and $2500 \mathrm{rpm}$. At each engine speed/load operating condition the effect of single pilot injection timing is presented for a fixed substitution ratio of $x=50 \%$. In addition, Figure 4 presents the peak cylinder pressure, IMEP g $_{\text {COV }}$ IMEPg and gross indicated thermal efficiency for all tested speed/load operating conditions. 

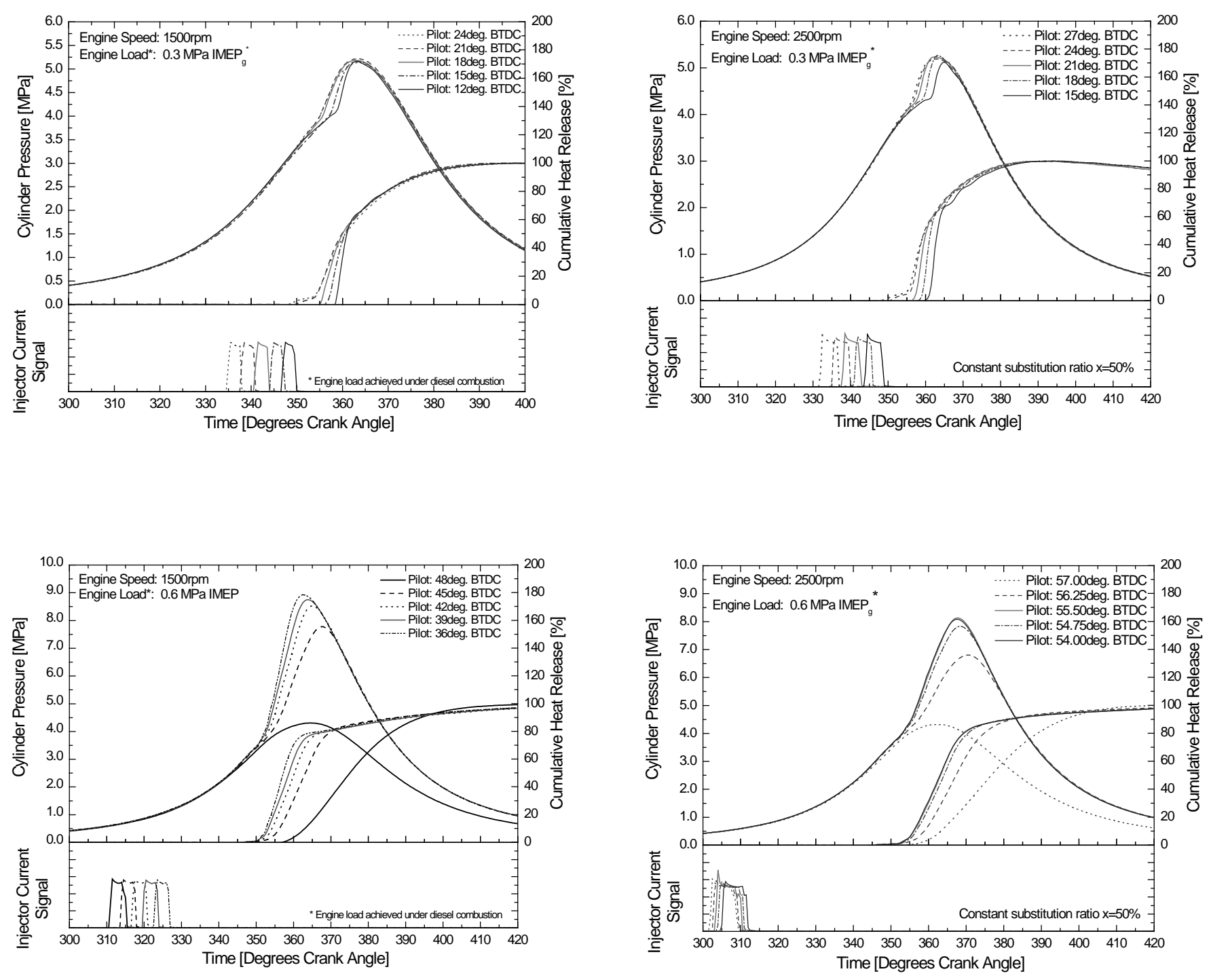

Figure 3. Effect of single diesel pilot injection timing on mean cylinder pressure and cumulative heat release rates for dual fuel combustion $(x=50 \%)$ at engine speeds of 1500 and 2500 rpm and loads of 0.3 and 0.6 MPa IMEPg* (IMEPg ${ }^{*}-$ Gross indicated mean effective pressure achieved under diesel combustion $(x=0 \%)$ ) 

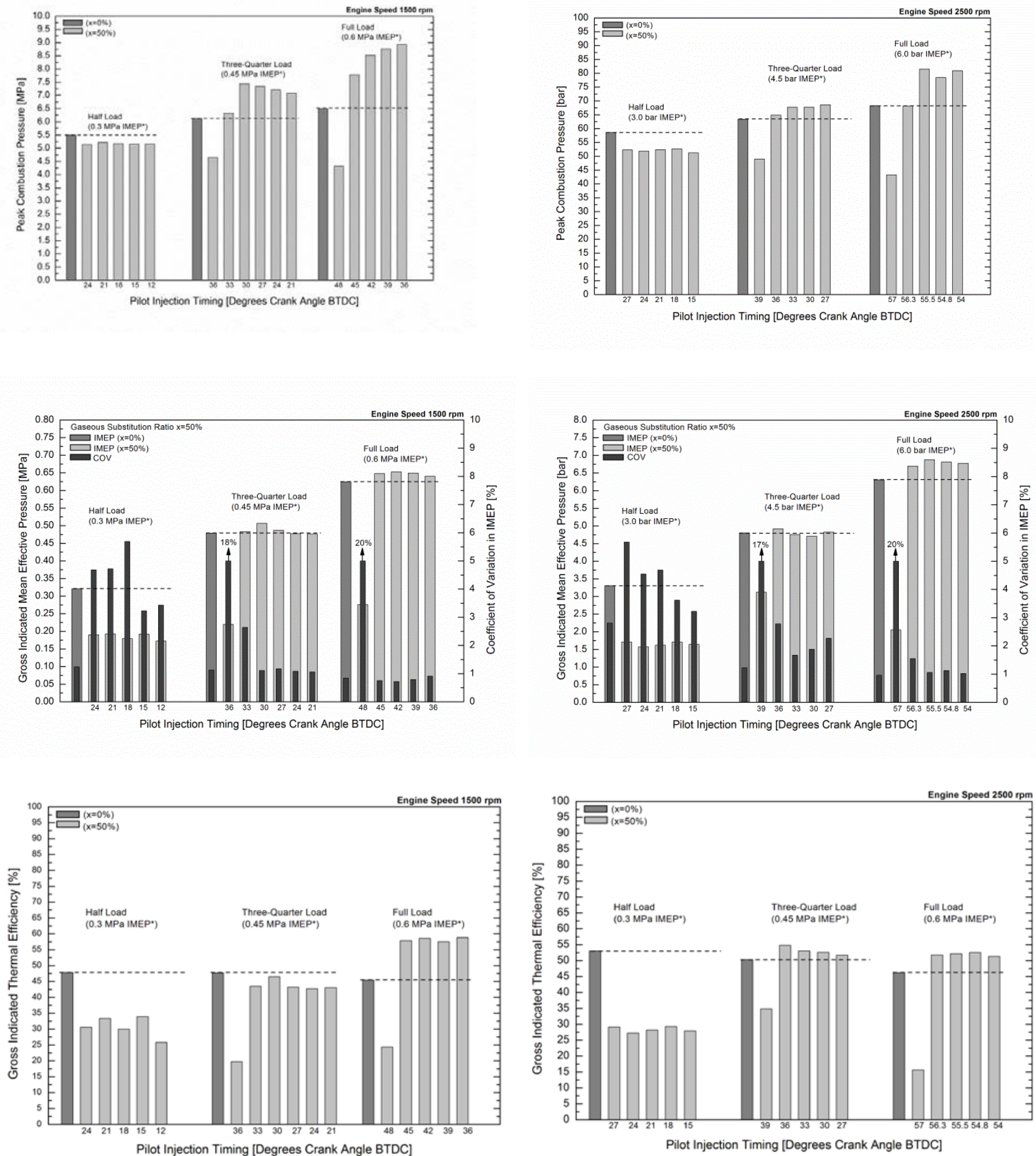

Figure 4. Effect of single diesel pilot injection timing on peak cylinder pressure, IMEPg, $\mathrm{COV}_{\mathrm{IMEPg}}$ and gross indicated thermal efficiency for dual fuel combustion (constant substitution ratio $x=50 \%$ ) at engine speeds of 1500 and $2500 \mathrm{rpm}$ and loads of 0.3, 0.45 and 0.6 MPa IMEP ${ }_{\mathrm{g}}^{*}$. Baseline diesel case ( $x=0 \%$ ) shown for reference. (IMEP ${ }_{\mathrm{g}} *$ - Gross indicated mean effective pressure achieved under diesel combustion $(x=0 \%)$ ) 
As previously discussed, for each engine operating condition the limit of pilot injection advance was governed by a $\mathrm{COV}_{\mathrm{IMEPg}}>5 \%$. Conversely, at the most retarded injection timing dual fuel combustion was limited by the maximum rate of pressure rise, $d P / d \theta>1.0 \mathrm{MPa}^{-1 e g^{-1}}$. At half load and $1500 \mathrm{rpm}$ no immediate heat release was evident following injection at the most advanced timing of 24 degrees crank angle $\left({ }^{\circ} \mathrm{CA}\right.$ ) before top dead centre (BTDC). Consequently, over-leaning of the mixture resulted in a slow rate of initial heat release once temperatures and pressures were sufficient for the diesel fuel to ignite. Figure 3 shows that it was approximately $5{ }^{\circ} \mathrm{CA}$ following the start of diesel combustion before any significant heat release from the premixed gaseous mixture was evident. This combustion delay resulting from the lean mixture being unable to support flame propagation and prevent complete utilisation of the energy contained within the gaseous fuel. Retarding the pilot diesel injection towards TDC reduced the ignition delay and increased the rate of heat release. The overall effect being to reduce the combustion duration at the most retarded injection timing of $12{ }^{\circ} \mathrm{CA}$ BTDC. However, over the tested pilot injection timings there was limited difference in the magnitude of peak cylinder pressure and calculated IMEPg for dual fuel combustion. At this low load operating condition the main difference was a decrease in $\mathrm{COV}_{\text {IMEPg }}$ from $4.7 \%$ to $3.4 \%$ as the pilot injection was retarded from $24{ }^{\circ} \mathrm{CA}$ to $12{ }^{\circ} \mathrm{CA}$ BTDC. For the same engine load, similar trends in heat release, peak pressure and IMEPg were shown to occur at the highest tested engine speed of $2500 \mathrm{rpm}$.

At full load, retarding the injection timing was shown to have a significant effect on the rates of heat release and peak cylinder pressures. Similarly to the half load case, the most advanced injection timing of $48{ }^{\circ} \mathrm{CA}$ BTDC at $1500 \mathrm{rpm}$ resulted in a slow rate of heat release and the longest combustion duration period. However, dual fuel combustion at high engine load was more sensitive to a change in pilot injection timing. Specifically, retarding the injection timing from $48{ }^{\circ} \mathrm{CA}$ BTDC to $45{ }^{\circ} \mathrm{CA}$ BTDC resulted in a significant increase in the rate of heat release and an increase in peak cylinder pressure from 
4.32 to $7.78 \mathrm{MPa}$. Furthermore, the calculated $\mathrm{IMEP}_{\mathrm{g}}$ increased from 0.28 bar to $0.65 \mathrm{MPa}$, the latter being $4.5 \%$ greater than the baseline diesel case. Retarding the injection timing further had less of an effect, with a peak pressure of 8.93 MPa and IMEP $\mathrm{g}_{\mathrm{g}}$ of $0.64 \mathrm{MPa}$ being achieved at the injection timing of $36{ }^{\circ} \mathrm{CA}$ BTDC. At this engine speed (1500 rpm) the main difference in dual fuel combustion was an improvement in combustion stability, highlighted by a reduction in $\mathrm{COV}_{\text {IMEPg }}$ from $5 \%$ to $0.9 \%$ as the injection timing was retarded from $48{ }^{\circ} \mathrm{CA}$ to $36{ }^{\circ} \mathrm{CA}$ BTDC. At the $2500 \mathrm{rpm}$ test condition, while similar trends were evident in the results, this occurred over a narrower injection timing range of $3{ }^{\circ} \mathrm{CA}$.

To summarise the effect of dual fuel combustion on engine performance the gross indicated thermal efficiency was calculated for the dual fuel results and compared with the baseline diesel case (Figure 4). The gross indicated thermal efficiency is calculated as the ratio of the work done during combustion to the total energy supplied by the fuels. For dual fuel operation, the total energy is a sum of the mass of the individual fuels multiplied by their respective lower heating values. As previously discussed, dual fuel operation was defined on an energy basis, whereby the total energy of the combined diesel and methane used for dual fuel combustion was equal to the total energy of the diesel injected at the baseline diesel operating condition. Therefore, the thermal efficiency is an indicator of the combustion quality, and encompasses the previously discussed parameters of heat release rates, cylinder pressure and IMEP. At half load (0.3 MPa IMEP $\left.{ }_{\mathrm{g}}{ }^{*}\right)$ a significant reduction, 33\%, was calculated for the dual fuel combustion compared to the baseline diesel cases (1500 rpm). A similar reduction in efficiency was shown to occur irrespective of pilot injection timing, highlighting the poor quality combustion at this low engine load operating condition. At high engine loads, retarding the injection timing resulted in significant improvements in the premixed gas combustion therefore increasing the calculated gross indicated thermal efficiency by 27\%. 
Dual fuel engine emissions. This section discusses the effect of a single pilot injection timing sweep on dual fuel engine emissions at engine speeds of 1500 and $2500 \mathrm{rpm}$ and engine loads of $0.3,0.45$ and 0.6 MPa IMEPg ${ }^{*}$. The specific (g.kWh${ }^{-1}$ ) emissions of $\mathrm{NO}_{\mathrm{x}}, \mathrm{CO}$ and tHC measured during dual fuel combustion ( $x=50 \%$ ) are presented in Figure 5. Exhaust gas temperature is also shown. For the purpose of comparison, the emissions results obtained from the baseline diesel ( $x=0 \%)$ testing are also included.

A significant improvement in the specific emission of $\mathrm{NO}_{\mathrm{x}}$ was achieved at the half load operating condition (1500 rpm), with an 89\% reduction being calculated at the most advanced pilot injection timing of $24{ }^{\circ} \mathrm{CA}$ BTDC. This reduction in $\mathrm{NO}_{\mathrm{x}}$ occurred as a result of reduced in-cylinder temperatures, therefore weakening the $\mathrm{NO}_{\mathrm{x}}$ formation mechanism. At this engine load, retarding the pilot injection timing from $24{ }^{\circ} \mathrm{CA}$ to $12{ }^{\circ} \mathrm{CA}$ BTDC only resulted in a $2 \%$ increase in specific $\mathrm{NO}_{\mathrm{x}}$ emission. For this pilot injection timing range, negligible difference in peak cylinder pressures was shown. Therefore, the slight increase in $\mathrm{NO}_{\mathrm{x}}$ is likely to result from the improvement in combustion stability (28\% reduction in $\mathrm{COV}_{\text {IMEP }}$ ), reducing the cycle-to-cycle variation in cylinder temperatures. At full load, a similar trend for increasing $\mathrm{NO}_{\mathrm{x}}$ emission with injection retard was evident. At the most advanced injection timing of 48 ${ }^{\circ} \mathrm{CA}$ BTDC the poor combustion efficiency and lower cylinder temperatures leads to a lower $\mathrm{NO}_{\mathrm{x}}$ emission compared to the baseline diesel case. Conversely, at the most retarded injection timing of 36 ${ }^{\circ} \mathrm{CA}$ BTDC the increase in cylinder pressure and therefore temperature results in a $43 \%$ increase in $\mathrm{NO}_{\mathrm{x}}$ emission. However, at a pilot injection timing of $45{ }^{\circ} \mathrm{CA}$ BTDC similar magnitudes of peak cylinder pressure and $\mathrm{IMEP}_{\mathrm{g}}$ were calculated for the dual fuel and baseline diesel cases, whilst also achieving a $27 \%$ reduction in specific $\mathrm{NO}_{\mathrm{x}}$. At the high engine speed of $2500 \mathrm{rpm}$, similar trends in $\mathrm{NO}_{\mathrm{x}}$ emission with injection retard were evident. However, the specific $\mathrm{NO}_{\mathrm{x}}$ emission remained lower than the baseline diesel case both half at and loads. 

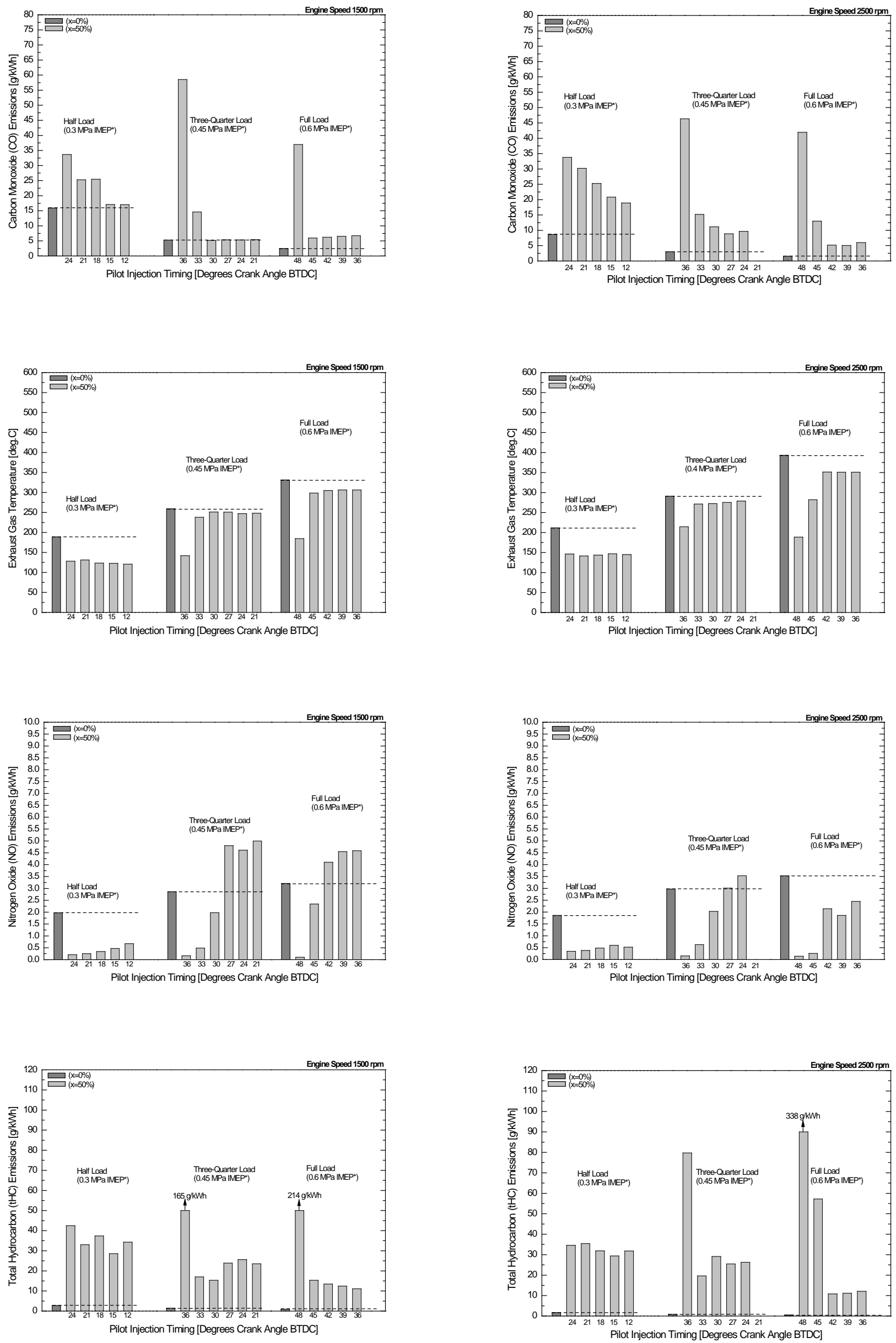
Figure 5. Effect of single diesel pilot injection timing on dual fuel engine emissions ( $\mathrm{NO}_{\mathrm{x}}, \mathrm{CO}$ and $\mathrm{uHC}$ ) (constant substitution ratio $x=50 \%$ ) at engine speeds of 1500 and 2500 rpm and loads of 0.3, 0.45 and 0.6 MPa IMEPg*.

Exhaust gas temperature is also shown. (IMEPg* - Gross indicated mean effective pressure achieved under diesel combustion $(x=0 \%))$ 
A higher specific CO emission was shown to occur during dual fuel combustion across all engine speeds, loads and pilot injection timings compared to the baseline diesel case. This increase being a result of partial oxidation of the gaseous fuel. Specifically, at half load and an engine speed of $1500 \mathrm{rpm}$, the CO emission was $111 \%$ and $7 \%$ higher than the baseline diesel at injection timings of $24{ }^{\circ} \mathrm{CA}$ and $12{ }^{\circ} \mathrm{CA}$ BTDC respectively. Similarly, at high load, retarding the pilot injection timing from $48{ }^{\circ} \mathrm{CA}$ to $36{ }^{\circ} \mathrm{CA}$ BTDC resulted in an increase in specific CO from 1390\% and 171\% compared to the baseline diesel. Considering only dual fuel combustion, the specific CO emission was particularly prominent at the most advanced injection timings, where the over-lean mixture was unable to support flame propagation, leading to partial oxidation of the gaseous fuel. Combining this with low charge temperatures and oxygen concentration within the cylinder, the $\mathrm{CO}$ emission was enhanced. Conversely, at the most retarded pilot injection timing a significant reduction in the specific $\mathrm{CO}$ emission was achieved. This reduction occurring as a result of improved oxidation of the gaseous fuel, highlighted by an increase in the rate of heat release.

The specific tHC emission from dual fuel combustion was significantly higher than that achieved during diesel combustion, irrespective of engine speed, load or pilot injection timing. This increase resulting from a combination of factors including incomplete combustion, containment within crevice volumes, flame quenching at combustion chamber walls and absorption into and subsequent desorption from oil layers. Considering only dual fuel combustion, the specific tHC emission was particularly prominent at the half load operating condition and the most advanced pilot injection timing. This increase resulting primarily from poor combustion quality and lower combustion temperatures, preventing oxidation of the uHC. Retarding the single pilot injection timing from $24^{\circ} \mathrm{CA}$ and $12{ }^{\circ} \mathrm{CA}$ BTDC resulted in a decrease in the tHC emission from 42.5 g. $\mathrm{kWh}^{-1}$ to 34.3 g. $\mathrm{kWh}^{-1}$. Increasing engine load during dual fuel combustion was shown to reduce the specific tHC emission. The improvement in tHC emission resulting from 
improved premixed gaseous combustion reducing the availability of unburned gaseous fuel, leading to increased cylinder temperatures and an increase in the uHC oxidation rate. This mechanism was further enhanced with injection retard, due to the increased rates of heat release leading to increased temperatures.

\section{Single pilot injection quantity}

The following section discusses the effect of pilot injection quantity on dual fuel performance for a constant engine speed of $1500 \mathrm{rpm}$. This was achieved by systematically reducing the mass of diesel contained within the pilot injection, while increasing the mass of gaseous fuel such that the total energy contained within the cylinder remained constant (i.e. substitution ratio sweep). This substitution ratio sweep was completed at the optimum single pilot injection timing for each engine speed and load operating condition, details of which are included in Table 7. The optimum timing being defined by the pilot injection timing that enabled the highest $\mathrm{IMEP}_{\mathrm{g}}$ to be achieved for the lowest $\mathrm{COV}_{\mathrm{IMEPg}}$. 
Table 7. Engine test conditions for dual fuel combustion operating a single pilot injection strategy

\begin{tabular}{|c|c|c|c|c|c|c|c|}
\hline \multirow{3}{*}{$\begin{array}{c}\text { Speed } \\
\text { [rpm] }\end{array}$} & \multirow{3}{*}{$\begin{array}{c}\text { Load } \\
\left(\mathrm{IMEP}_{\mathrm{g}}{ }^{*}\right) \\
{[\mathrm{MPa}]}\end{array}$} & \multirow{3}{*}{$\begin{array}{l}\text { Pilot Injection } \\
\text { Timing } \\
\text { [ }{ }^{\circ} \mathrm{CA} \text { BTDC] }\end{array}$} & \multicolumn{5}{|c|}{ Dual Fuel Combustion, IMEPg [bar] } \\
\hline & & & \multicolumn{5}{|c|}{ Substitution Ratio $(x)$} \\
\hline & & & $30 \%$ & $40 \%$ & $50 \%$ & $60 \%$ & $70 \%$ \\
\hline \multirow{4}{*}{1500} & 0.15 & - & & & & & \\
\hline & 0.3 & 15 & 2.95 & 2.96 & 1.92 & 2.51 & \\
\hline & 0.45 & 24 & 3.51 & 4.73 & 4.78 & 4.45 & 4.21 \\
\hline & 0.6 & 42 & 5.43 & 6.12 & 6.53 & 7.22 & 7.45 \\
\hline
\end{tabular}

IMEPg* - Gross indicated mean effective pressure achieved under diesel combustion $(x=0 \%)$

${ }^{\circ} \mathrm{CA}$ BTDC - Degrees crank angle before top dead centre

$\mathrm{IMEP}_{\mathrm{g}}$ - Gross indicated mean effective pressure

Dual fuel engine performance. The effect of gas substitution on the calculated mean cylinder pressure trace and cumulative heat release rates during dual fuel combustion at 0.3 and $0.6 \mathrm{MPa} \mathrm{IMEP}_{\mathrm{g}}{ }^{*}$ are

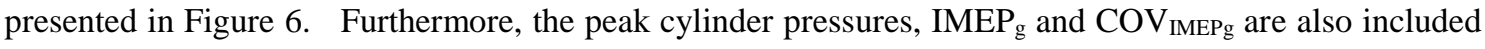
for each tested engine operating condition.

The variation in IMEP $_{\mathrm{g}}$ occurs as a direct consequence of changes in heat release rates impacting upon the cylinder pressure profile. Consequently, results show a dependency of the IMEP $\mathrm{g}_{\mathrm{g}}$ achieved during dual fuel combustion on engine load and substitution ratio. At low load ( $\left.0.3 \mathrm{MPa} \mathrm{IMEP}_{\mathrm{g}}{ }^{*}\right), x=30 \%$, the calculated $\mathrm{IMEP}_{\mathrm{g}}$ during dual fuel combustion is approximately 8\% less than that of the diesel case. Furthermore, at this half load operating condition increasing the substitution ratio resulted in a reduction in the peak cylinder pressure and a decrease in combustion stability. Specifically, an increase in substitution ratio from $x=30 \%$ to $x=60 \%$ resulted in a $14 \%$ reduction in IMEP $_{\mathrm{g}}$ and an increase in $\mathrm{COV}_{\text {IMEPg }}$ from $2.5 \%$ to $3.6 \%$. As engine load was increased the total mass of diesel entering the cylinder 
increased leading to improved flame propagation during the premixed combustion phase and therefore greater utilisation of the energy contained within the gaseous fuel. As the pilot injection was optimised for a substitution ratio of $x=50 \%$, at substitution ratios less than $50 \%$ a lower peak cylinder pressure and IMEPg were shown to occur, with the main improvements in engine performance being achieved at $x>$ $50 \%$. Specifically, at full load ( $\left.0.6 \mathrm{MPa}_{\mathrm{IMEP}}{ }^{*}\right), x=30 \%$, the IMEPg was calculated to be $13 \%$ lower than the baseline diesel, whereas at $x=70 \%$, the IMEPg was calculated to be $19 \%$ higher. At this high load operating condition, the combustion stability during dual fuel operation was also shown to reduce, with similar levels in $\mathrm{COV}_{\text {IMEPg }}\left(0.5 \%<\mathrm{COV}_{\text {IMEPg }}<1.0 \%\right)$ to the baseline diesel case being calculated. 

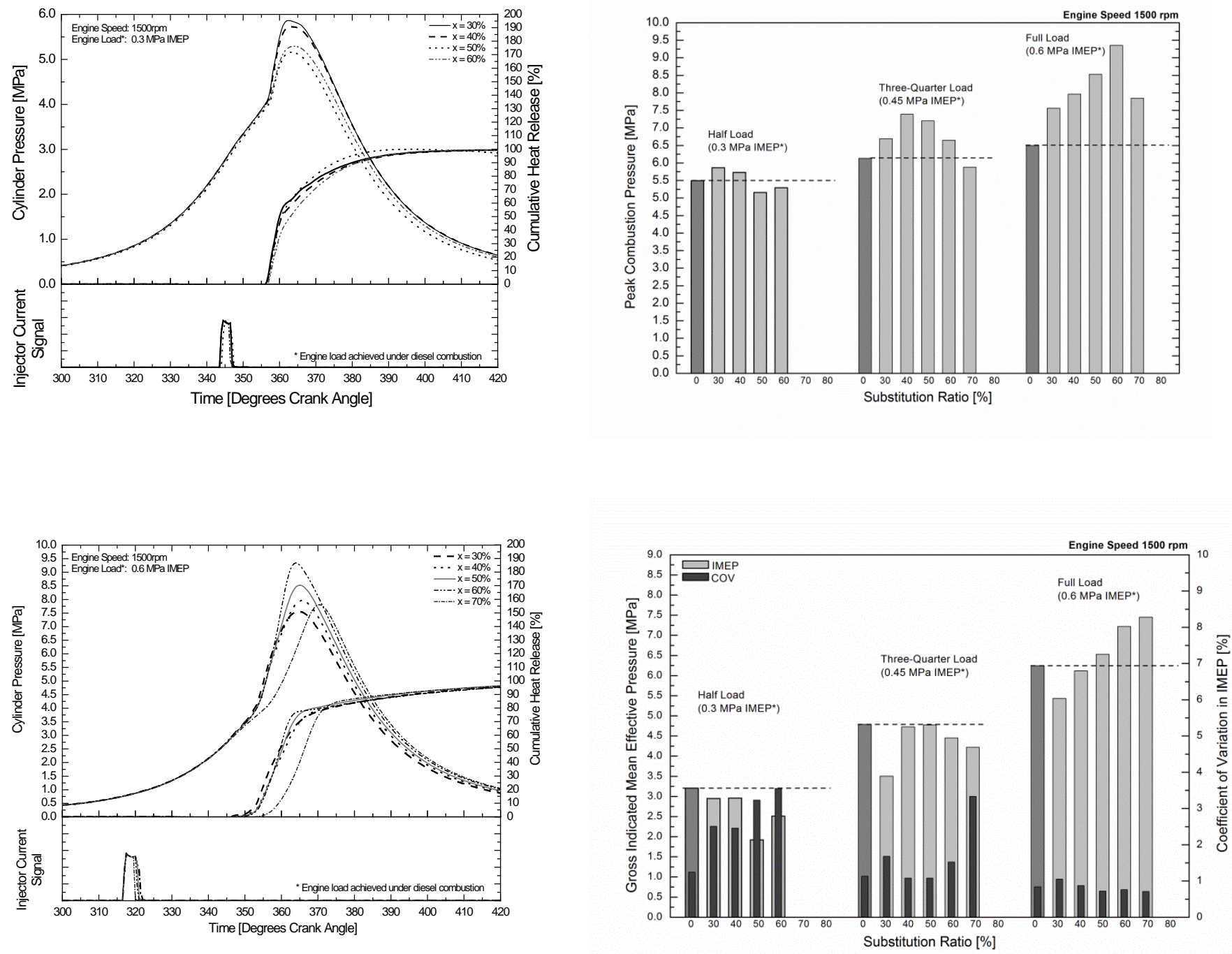

Figure 6. Effect of substitution ratio $(x)$ on mean cylinder pressure and cumulative heat release rates for dual fuel combustion operating with a single pilot injection at a constant engine speed of 1500 rpm for loads of 3.0 and 6.0 bar IMEPg*. Peak combustion pressure, gross indicated mean effective pressure (IMEPg) and COV IMEPg shown for loads of 0.3, 0.45 and 0.6 MPa IMEPg*. (IMEPg* - Gross indicated mean effective pressure achieved under diesel combustion $(x=0 \%))$ 
Dual fuel engine emissions. The effect of gas substitution on the specific (g.kWh-1) emissions of $\mathrm{NO}_{\mathrm{x}}$, $\mathrm{CO}$ and tHC measured during dual fuel combustion are presented in Figure 7. The specific emissions are shown to be dependent on the quantity of fuel contained within the pilot injection and hence the overall substitution ratio. At half load the specific $\mathrm{NO}_{\mathrm{x}}$ emissions measured during dual fuel combustion were significantly less (> 14\% reduction) than the baseline diesel case. This decrease resulting from poor quality combustion of the gaseous fuel/air mixture reducing cylinder temperatures and therefore weakening the $\mathrm{NO}_{\mathrm{x}}$ formation mechanism. Reducing the quantity of diesel fuel contained within the pilot injection (i.e. increasing substitution ratio) had a detrimental effect on combustion quality. This was a result of the reduced number of ignition sites leading to poor utilisation of the energy contained within the premixed gaseous mixture. Consequently, in-cylinder temperatures were reduced, hence weakening the $\mathrm{NO}_{\mathrm{x}}$ formation mechanism, although at the cost of reduced engine power output. Conversely, at full load $\left(0.6 \mathrm{MPa} \mathrm{IMEP}_{\mathrm{g}}{ }^{*}\right)$ the increase in fuel contained in the pilot injection increases the number of ignition sites within the cylinder. This results in an increase in burn rate and higher peak pressures occurring earlier in the engine cycle. The associated increase in charge temperature and time available for oxidation reactions to occur leads to an overall enhancement of the $\mathrm{NO}_{\mathrm{x}}$ formation rate. The trend in specific $\mathrm{NO}_{\mathrm{x}}$ emissions at full load was therefore shown to be the opposite of that measured for the half load case. However, at a substitution ratio of $x=40 \%$ a $27 \%$ decrease in specific $\mathrm{NO}_{\mathrm{x}}$ emission was achieved, with only a slight (2\%) decrease in IMEP $_{\mathrm{g}}$.

Comparison of the specific CO emission at half load, highlighted a reduction in CO emission of approximately $7 \%$ during dual fuel combustion $(x<50 \%)$ compared to the baseline diesel case. However, increasing substitution was shown to have a negative (increasing) effect on CO emission, with a $20 \%$ increase in CO compared to the baseline diesel case at the highest substitution ratio of $x=60 \%$. At these high substitution ratios, the lean mixture is unable to support flame propagation leading to 
partially oxidised fuel, reduced cylinder temperatures and consequently an increase in CO emission. In contrast, at high load, the specific CO emission was calculated to be approximately $150 \%$ greater than the baseline diesel case $(x=50 \%)$. Furthermore, increasing substitution ratio $x=30 \%$ to $x=70 \%$ resulted in a decrease in CO emission from 13.5 g.kWh-1 to 3.0 g.kWh ${ }^{-1}$, with the latter being $20 \%$ greater than the conventional diesel case.

Considering the specific emission of tHC, dual fuel combustion results in a significant increase in tHC emission compared to the baseline diesel case. At half load, the combined effect of a richer gaseous mixture contained within crevice volumes, poor combustion quality and lower cylinder temperatures preventing oxidation of the uHC, leads to an increase in tHC emissions. This tHC formation is therefore enhanced as substitution ratios are increased, since the gas concentration is increased. Conversely, at full load the opposite effect was achieved with a decrease in specific tHC emission from $23.1 \mathrm{~g}^{\mathrm{kWh}}{ }^{-1}$ to 7.6 g.kWh ${ }^{-1}$, as the substitution ratio was increased from $x=30 \%$ to $x=70 \%$. This reduction in tHC emission resulting from improved combustion quality and oxidation of the gaseous fuel. 

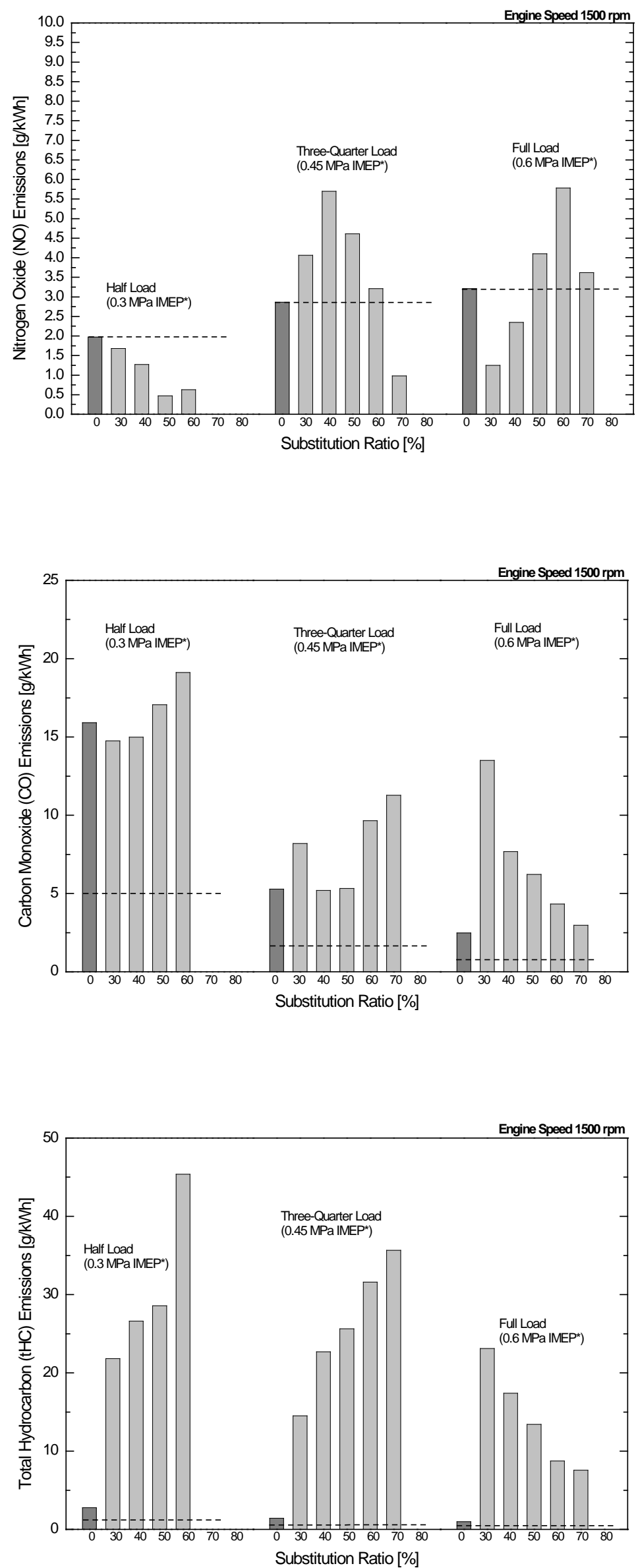
Figure 7. Effect of substitution ratio $(x)$ on dual fuel combustion emissions $\left(\mathrm{NO}_{\mathrm{x}}, \mathrm{CO}\right.$ and $\left.\mathrm{uHC}\right)$ at a constant engine speed of $1500 \mathrm{rpm}$ for loads of 0.3, 0.45 and 0.6 MPa IMEPg*. (IMEPg ${ }^{*}$ - Gross indicated mean effective pressure achieved under diesel combustion $(x=0 \%))$ 
A particular advantage of dual fuel combustion is the potential for significant reductions in specific $\mathrm{CO}_{2}$. Since dual fuel engines substitute the liquid fuel with a gaseous fuel of a lower carbon-to-hydrogen ratio, they produce lower $\mathrm{CO}_{2}$ emissions per unit volume and energy of fuel used. This $\mathrm{CO}_{2}$ advantage is shown in Figure 8, highlighting a 61\% and 30\% improvement in specific $\mathrm{CO}_{2}$ emission at half and full loads (1500 rpm), for substitution ratios of $x=50 \%$.

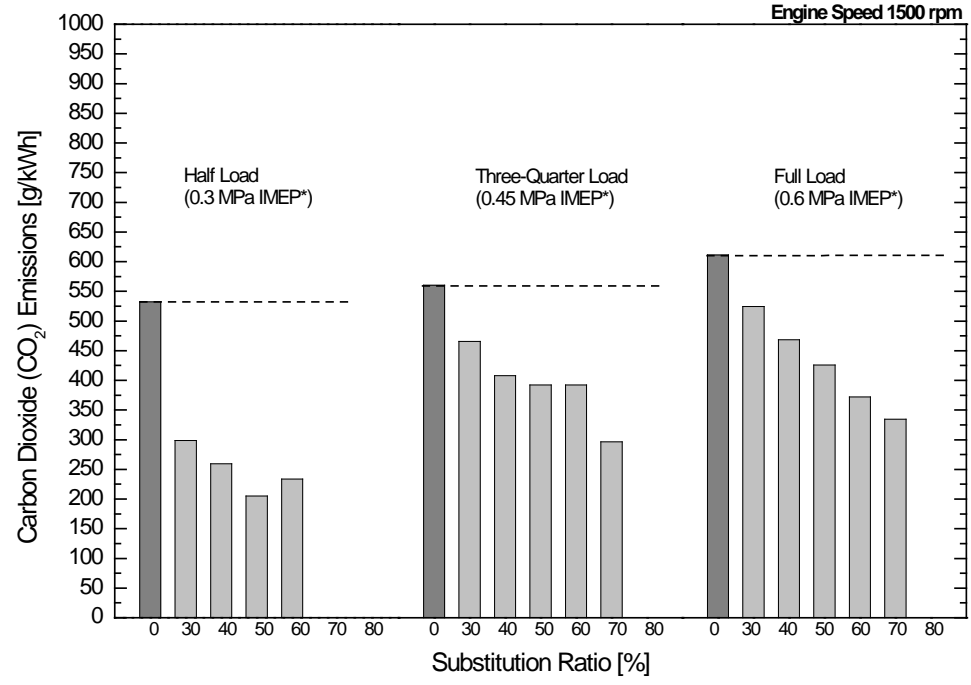

Figure 8. Effect of substitution ratio $(x)$ on specific $\mathrm{CO}_{2}$ emission at a constant engine speed of 1500 rpm for loads of 0.3, 0.45 and 0.6 MPa IMEP I $^{*}$ IMEP $_{\mathrm{g}}$ * - Gross indicated mean effective pressure achieved under diesel combustion $(x=0 \%))$

Figure 9 shows the effect of dual fuelling an engine in terms of visible smoke. At both $1500 \mathrm{rpm}$ and 2500 rpm speeds and all load cases tested it was possible to obtain a reduction in smoke.
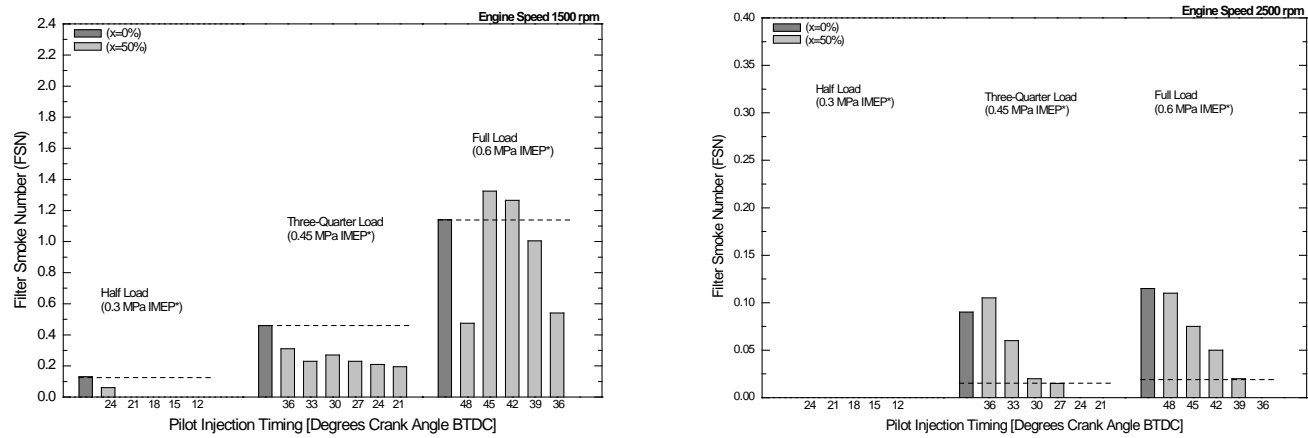

Figure 9. Effect of single diesel pilot injection timing on dual fuel engine smoke emissions (constant substitution ratio $x=50 \%$ ) at engine speeds of 1500 and $2500 \mathrm{rpm}$ and loads of $0.3,0.45$ and $0.6 \mathrm{MPa}$ IMEP ${ }_{\mathrm{g}}^{*}$. (IMEP $\mathrm{I}_{\mathrm{g}}$ - Gross indicated mean effective pressure achieved under diesel combustion $(x=$ $0 \%)$ 


\section{Conclusions}

The dual fuel combustion of a small capacity high speed common rail internal combustion engine was achieved at engine speeds of 1500 and $2500 \mathrm{rpm}$ and loads of 0.3, 0.45 and 0.6 MPa IMEP ${ }_{\mathrm{g}}^{*}$. The effect of a single injection timing sweep on dual fuel combustion and emissions was completed and compared to a baseline diesel case. Furthermore, for a fixed engine speed and single pilot injection strategy, the effect of gas substitution ratio on dual fuel combustion was discussed. The following conclusions can be drawn from the research into the effect of single pilot injection timing and constant substitution ratio of $x=$ 50\%:

1. For a single pilot injection timing sweep, the maximum injection advance was governed by a $\mathrm{COV}_{\text {IMEPg }}>5 \%$. Conversely, the maximum injection retard was governed by the maximum rate of pressure rise, $d P / d \theta>1.0 \mathrm{MPa} \cdot \mathrm{deg}^{-1}$.

2. For a constant fuel energy, dual fuel combustion was shown to be dependent on engine load and pilot injection timing. At half load and fixed substitution ratio, peak cylinder pressure and IMEP $_{\mathrm{g}}$ were less than the baseline diesel condition resulting in a lower gross indicated thermal efficiency. At high load a higher peak cylinder pressure and improvement in IMEP $\mathrm{g}_{\mathrm{g}}$ were achieved during dual fuel combustion compared the baseline diesel case, resulting in an improvement in the gross indicated thermal efficiency.

3. The specific CO emission was shown to increase for all speeds and loads during dual fuel combustion, compared to the baseline diesel case. However, an improvement (reduction) in CO was achieved as pilot injection timing was retarded. 
4. A significant improvement in the $\mathrm{NO}_{\mathrm{x}}$ emission was achieved at low engine load during dual fuel combustion, although an increase was evident as the pilot injection timing was retarded. Conversely, the improvement in combustion quality and increase in cylinder temperatures at high load resulted in an increase in $\mathrm{NO}_{\mathrm{x}}$ compared to the baseline diesel case and further increases at retarded injection timings.

5. The specific emission of tHC during dual fuel combustion was shown to be higher than that achieved during conventional diesel combustion. This increase was shown to be most prominent at the most advanced injection timings and low engine loads.

The following conclusions can be drawn from the research investigating the effect of pilot injection quantity (i.e. substitution ratio) on dual fuel engine performance and emissions:

1. At low engine load, reducing the mass of diesel within the pilot injection but maintaining a constant total fuel energy resulted in a reduction in peak cylinder pressure and IMEPg. Furthermore, this increase in substitution ratio resulted in a worsening of the combustion stability, indicated by an increase in $\mathrm{COV}_{\text {IMEPg. }}$ Conversely, at high load, an increase in substitution ratio resulted in an increase in peak pressure and $\mathrm{IMEP}_{\mathrm{g}}$ and an improvement in the combustion stability.

2. The effect of substitution ratio on the specific emissions during dual fuel combustion was shown to be dependent on engine load. At half load, $\mathrm{NO}_{\mathrm{x}}$ was shown to decrease with increasing substitution ratio, while CO increased. In contrast, at full load NO increased and CO decreased. 
At both engine loads, although the tHC emission was significantly higher than the baseline diesel case, increasing substitution ratio had a positive (decreasing) effect on tHC emission.

3. Significant reductions in specific $\mathrm{CO}_{2}$ emission were achieved during dual fuel combustion compared to the baseline diesel case. Specifically, $\mathrm{CO}_{2}$ reductions of $61 \%$ and $30 \%$ were achieved at half and full loads for an engine speed of $1500 \mathrm{rpm}$.

\section{Acknowledgements}

The authors would like to thank Adrian Broster, Steve Horner, Graham Smith and Steve Taylor for their assistance during the engine and test cell modifications to achieve dual fuel combustion.

\section{Funding}

This work was supported by the UK Engineering and Physical Sciences Research Council (EPSRC) [grant number EP/H050388/1].

\section{References}

1. European commission. Road transport: reducing $\mathrm{CO}_{2}$ from vehicles, http://ec.europa.eu/environment/air/transport/co2/co2_cars_regulation.htm (2012, Accessed 22 October 2012).

2. Rimmer, J.E.T., Johnson, S.L., Clarke, A. An experimental study into the effect of gas substitution ratio on the performance and emissions of a high speed common rail dual fuel engine. Proc ImechE, Part D: Journal of Automobile Engineering (JAUTO-12-0005).

3. Selim, M.Y.E. Sensitivity of dual fuel engine combustion and knocking limits to gaseous fuel composition. Energy Convers. Manage. 2004; 25: 411-425. 
4. Bradley, D., Lawes, M., Shepherd, C.G.W., and Woolley, R. Methane as an engine fuel. In: IMechE Using natural gas in engines. London: Mechanical Engineering Publications for the ImechE, 1996, pp.9-15.

5. Patterson, J., Clarke, A., and Chen, R. An experimental study of the dual-fuel performance of a small compression ignition diesel engine operating with three gaseous fuels. Proc ImechE, Part D: Journal of Automobile Engineering 2007; 221: 943-956.

6. Karim, G.A. Combustion in gas fuelled compression: ignition engines of the dual fuel type. J. Eng. Gas Turbines Power 2003; 125: 827-836.

7. Daisho, Y., Yaeo, T., Koseki T., Saito, T., Kihara, R., and Quiros E,N. Combustion and exhaust emissions in a direct-injection diesel engine dual-fueled with natural gas. SAE Paper 950465, 1995.

8. Sahoo, B.B., Sahoo, N., and Saha, U.K. Effects of Engine parameters and type of gaseous fuel on the performance of dual-fuel diesel engines-A critical review. Renewable and Sustainable Energy Reviews 2009; 13: 1151-1184.

9. Cong, S., McTaggart-Cowan, G.P., and Garner, C.P. Measurement of residual gas fraction in a single cylinder HSDI diesel engine through skip-firing. SAE Paper 2009-01-1961, 2009.

10. Heywood, J.B. Internal combustion engine fundamentals. New York: McGraw-Hill, 1988.

\section{Appendix 1}

\section{Abbreviations}

ATDC After top dead centre

BTDC Before top dead centre

CA Crank angle (degrees)

CO Carbon monoxide

$\mathrm{CO}_{2} \quad$ Carbon dioxide 


$\begin{array}{ll}\text { COV } & \text { Coefficient of variation } \\ \text { IMEPg } & \text { Gross indicated mean effective pressure (bar) } \\ \mathrm{NO}_{x} & \text { Nitrogen oxide } \\ \mathrm{O}_{2} & \text { Oxygen } \\ \text { PAH } & \text { Polycyclic aromatic hydrocarbon } \\ \text { RoHR } & \text { Rate of heat release } \\ \text { STP } & \text { Standard temperature and pressure } \\ \text { TDC } & \text { Top dead centre } \\ \text { tHC } & \text { Total hydrocarbons } \\ \text { uHC } & \text { Unburned hydrocarbons } \\ \text { VCO } & \text { Valve covered orifice }\end{array}$

